\title{
Inflammatory bowel disease: outpatient treatment profile
}

\author{
Rachael Miranda dos SANTOS ${ }^{1,2}$, Ana Teresa Pugas CARVALHO ${ }^{1}$, Kelly dos Santos SILVA', \\ Selma Petra Chaves SÁ ${ }^{2}$, Aparecida Helena dos SANTOS $^{2}$ and Millene Ramos SANDINHA ${ }^{1}$
}

\begin{abstract}
Background - Crohn's disease and ulcerative colitis are the two major forms of inflammatory bowel disease. The incidence and prevalence of both conditions have increased and are progressively increasing. These diseases are frequently recurrent and clinically highly severe. In Brazil, the lack of epidemiological data related to such diseases has left these patients in a vulnerable state and contributed to increased morbidity. Objective - To describe the profiles of patients with inflammatory bowel disease treated in an outpatient service in Brazil. Methods - This descriptive, exploratory, and retrospective documentary study with a quantitative approach was performed in an outpatient treatment service for inflammatory bowel disease, at a university polyclinic located in Rio de Janeiro, Brazil, from May to July 2016. The study included 556 patients and was approved by the research ethics committee of the institution (CAAE no. 55179316.6.0000.5259/2016). Results - The data showed a high prevalence of inflammatory bowel disease in white female patients. Crohn's disease was diagnosed in more patients than was ulcerative colitis; the ileocolon was the most commonly affected location in patients with Crohn's disease. The stenotic phenotype was prevalent in patients with Crohn's disease. Conclusion - The prevalence of the stenotic phenotype in Crohn's disease in relation to others demonstrates the need for further investigations in this field of study in Brazil. In conclusion, the data showed that the epidemiologic profile of the study population is similar to that published in the national and international literature.

HEADINGS - Inflammatory bowel diseases. Crohn disease. Ulcerative colitis. Epidemiology.
\end{abstract}

\section{INTRODUCTION}

Crohn's disease (CD) and ulcerative colitis (UC) are the two major inflammatory bowel diseases (IBDs) that affect 1 in 200 people in developed countries, where they present an increasing incidence and prevalence. In European countries, at least a five-fold increase in the incidence of IBD in the last 30 years has been estimated ${ }^{(5,15)}$.

IBD generally causes debilitating symptoms such as urgent diarrhea, rectal bleeding, vomiting, and anorexia, which often have an adverse effect on the social, professional, academic, family relationships, and sexual activity of patients ${ }^{(3,5,14,15)}$.

$\mathrm{UC}$, which involves only the rectum and colon, usually develops in the rectum (proctitis) and may extend proximally to the sigmoid and descending colon (left sided colitis) or the entire colon (pancolitis). The location and disease activity index determine the therapeutic approach ${ }^{(2)}$.

CD may affect the gastrointestinal tract anywhere between the mouth and the anus; inflammation occurs intermittently, with spots caused by the disease in areas of healthy mucosa. CD may be classified as inflammatory, stenotic, or penetrating. The genetic component is more prevalent in CD than in UC. Other rheumatologic, dermatologic, ophthalmologic, hepatobiliary, and extraintestinal diseases may occur concomitantly ${ }^{(2)}$.

Among the various classifications proposed for UC and CD, the Montreal classification is the most commonly used as it distinguishes clinical subphenotypes of CD according to location, behavior, and age at symptom onset, and those of ulcerative colitis according to the extent of the disease and age at symptom onset. Such a classification is desirable for correlating specific disease phenotypes with possible clinical outcomes and prognosis to select a better therapeutic approach and a more appropriate follow-up for each patient ${ }^{(4,5)}$.

Reference centers responsible for treating patients with IBD are often required to justify their need for resources in order to provide appropriate treatments for patients. Studies have shown that the costs related to treating patients with IBD are nearly 2.2 billion dollars per year in the United States ${ }^{(15)}$.

In Brazil, patients with $\mathrm{CD}$ and $\mathrm{UC}$ are not necessarily reported resulting in a lack of epidemiologic data with respect to these diseases. This situation places patients in a vulnerable state, as incipient studies and the poor publication records on this group of diseases contribute to their late diagnosis and increased morbidity ${ }^{(3,4,6,8,9,14)}$.

It is difficult to determine the epidemiologic data of IBD in Brazil and all developing countries owing to deficiencies in data recording systems and the inability to access data other than those in the public health system. Given this reality, specialty pharmacies and reference centers for the treatment of IBD are favorable places for performing IBD-related studies ${ }^{(6,8,9,14)}$

The outpatient follow-up of patients with IBD aims to control symptoms and induce disease remission, adapt patients to their chronic condition and improve their quality of life, minimize toxicity and monitor the adverse effects of prescribed drugs, and postpone or reduce the incidence of relapse ${ }^{(1)}$.

Therefore, this study aimed to describe the profile of patients with IBD in a university outpatient service in Rio de Janeiro.

Declared conflict of interest of all authors: none

Disclosure of funding: no funding received

1 Ambulatório de Doenças Inflamatórias Intestinais, Disciplina de Gastroenterologia, Policlínica Piquet Carneiro, Universidade do Estado do Rio de Janeiro, Rio de Janeiro, RJ, Brasil. ${ }^{2}$ Programa de Mestrado Profissional em Enfermagem Assistencial, Escola de Enfermagem Aurora Afonso Costa, Universidade Federal Fluminense, Niterói, RJ, Brasil.

Correspondence: Rachael Miranda dos Santos. Serviço Ambulatorial de Gastroenterologia, Policlínica Piquet Carneiro, Universidade do Estado do Rio de Janeiro. CEP: $20950-003$ - Rio de Janeiro, RJ, Brasil. E-mail: rachaelmiranda@id.uff.br 


\section{METHODS}

This retrospective, documentary, and descriptive quantitative study was performed in an outpatient treatment service for IBD of a University Polyclinic located in Rio de Janeiro. The study was performed between May and July 2016, and included 556 patients. This investigation followed the ethical guidelines recommended by the Brazilian National Committee for Ethics in Research of the Brazilian National Health Council, and was approved by the Research Ethics Committee of the Institution (CAAE no. 55179316.6.0000.5259/2016).

The inclusion criteria were patients with IBD registered in the outpatient service for IBD treatment and undergoing outpatient treatment during the data collection period. Patients who had undergone treatment for $<3$ months were excluded from the study owing to the lack of necessary data for surveying their full profile.

The variables studied were sex, age, demographic data, diagnosis, disease location, intestinal CD phenotype, effective treatment, previous surgeries, and the occurrence of perianal disease.

The data were retrieved from medical records by using an appropriate data collection tool that enabled the collection of the socio-demographic, clinical, endoscopic, radiologic, and imaging profiles of each study participant.

Age was analyzed as a continuous variable, whereas the average and minimum and maximum values were retrieved and analyzed by using a line chart to find the prevalence peaks according to age.

The Montreal classification, which subdivides the disease according to three main phenotypic characteristics, i.e. age at diagnosis (A, "age"), topographic location (L, "location"), and clinical behavior (B, "behavior"), was used to categorize the CD location. The location is defined as the point of the maximum anatomical extent of the disease at any time. There were four possible classifications according to location: terminal ileal (L1, limited to the lower third of the small intestine, with or without cecal involvement), colonic (L2, anywhere between the cecum and the rectum without involvement of the upper digestive tract), ileocolonic (L3, terminal ileum and anywhere between the ascending colon and rectum), and isolated to the upper gastrointestinal tract (L4, anywhere above the terminal ileum, except the mouth). If there is a simultaneous proximal (L4) and distal (L1-L3) involvement, an L4 category should be added as a modifier; if no distal involvement was found, L4 was considered to be of the exclusive form. This resulted in seven possible classifications according to location: L1, L2, L3, $\mathrm{L} 4, \mathrm{~L} 1+\mathrm{L} 4, \mathrm{~L} 2+\mathrm{L} 4$, and $\mathrm{L} 3+\mathrm{L} 4^{(4,10)}$.

Concerning the clinical behavior of $\mathrm{CD}$, three classifications were used: nonstenotic and nonpenetrating/inflammatory (B1), stenotic (B2), and penetrating/fistulizing (B3). Nonstenotic and nonpenetrating/inflammatory clinical behavior (B1) occurs in the presence of inflammation without any stenotic or fistulizing evidence. On the other hand, stenotic behavior (B2) is defined by a narrowing of the intestinal lumen. Penetrating behavior (B3) is defined when abdominal fistulae or inflammatory masses and/or abscess occur at any period during the progression of disease $^{(4,10,12,15)}$.

To ensure correct classification and differentiation of the clinical behavior of $\mathrm{CD}$, data from enterography reports obtained from magnetic resonance imaging or computed tomography scans were used preferentially, as well as endoscopic reports of the study patients when appropriate.
The extent of UC was classified as follows: ulcerative proctitis (E1), involvement limited to the rectum; left colitis (E2), involvement extending to the splenic flexure; and extensive colitis (E3), involvement extending beyond the splenic flexure ${ }^{(3,5)}$.

The data were processed, stored, and analyzed by using Microsoft Excel 2010 and the Statistical Package for Social Sciences version 20.0. For characterization of the sample and descriptive analysis of the variables, the data were summarized by using descriptive statistics in frequency distribution tables. The results were discussed and compared with the data of currently available relevant studies.

\section{RESULTS}

Among the 556 patients with IBD who participated in the study, $331(59.3 \%)$ were women and $225(40.7 \%)$ were men. The median age of the 432 participants was 49.7 years ,range, 15-86 years (Figure 1).

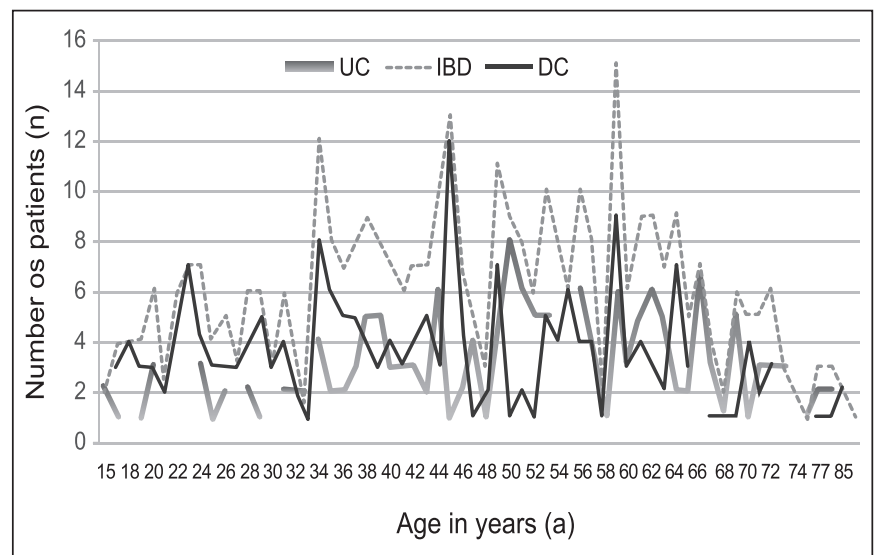

FIGURE 1. Distribution of inflammatory bowel disease (IBD), Crohn's disease (CD), and ulcerative colitis (UC) in patients according to age. Rio de Janeiro, Brazil, 2016.

The data relative to the places of residence of the participants showed that most of the patients treated at the outpatient service lived in the same municipality $(53.70 \% ; n=290)$, whereas those from the other 33 neighboring municipalities in the city of Rio de Janeiro were also identified. The patient with the farthest residence was living $344 \mathrm{~km}$ away from the reference center. Considering the regional distribution in the state, most of the treated patients were living in the metropolitan region $(94.32 \% ; n=382)$, followed by those who were living in the Coastal Lowlands region $(2.72 \% ; n=11)$, Northern Rio de Janeiro $(1.23 \% ; n=5)$, Costa Verde $(0.74 \% ; n=3)$, and Middle Paraíba and Central-South Rio de Janeiro $(0.25 \%$; $\mathrm{n}=1$ each). The other patients $(0.49 \% ; n=2)$ were living in other states of the southeastern region of Brazil.

Concerning race/self-reported color, the data of 431 patients were surveyed: $47.80 \%(\mathrm{n}=206)$ self-reported as white, $38.52 \%$ $(\mathrm{n}=166)$ as dark skinned, and $13.69 \%(\mathrm{n}=59)$ as black.

The medical diagnoses included the data of 447 patients. CD was found in $56.38 \%(\mathrm{n}=252)$ and $\mathrm{UC}$ was found in $38.26 \%(\mathrm{n}=171)$, whereas $5.37 \%(\mathrm{n}=24)$ of patients were lacking a diagnosis.

The most common types of UC according to inflammatory location were extensive colitis (E3) $35.67 \%,(n=61)$ and proctitis (E1) $30.99 \%,(n=53)$ (Figure 2). 


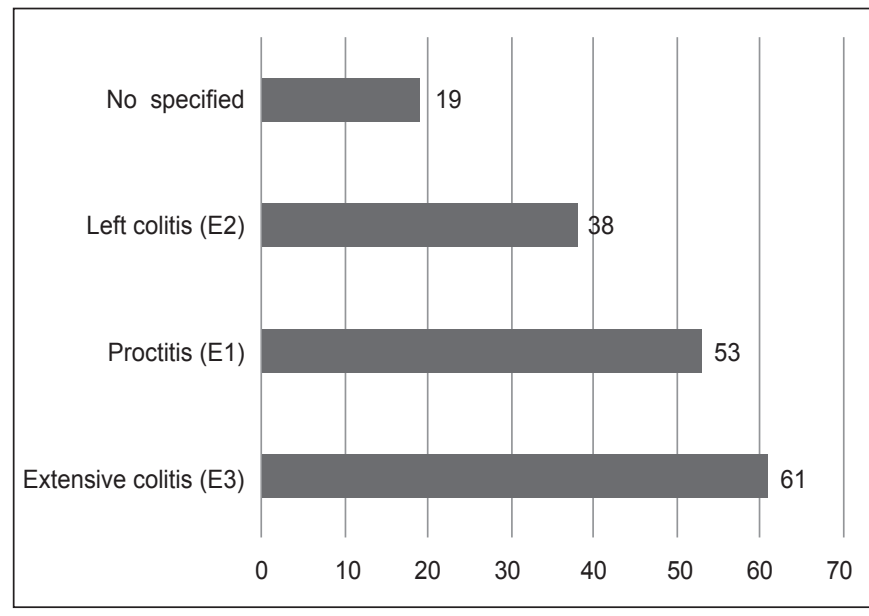

FIGURE 2. Number of patients with ulcerative colitis according to inflammatory location. Rio de Janeiro, Brazil, 2016.

The data from 88 patients with $\mathrm{CD}$ were surveyed according to the Montreal classification; the most prevalent type of CD according to location was ileocolonic (L3) $(57.95 \%, \mathrm{n}=51)$, followed by colonic (L2) $(18.18 \%, \mathrm{n}=16)$, ileal (L1) $(11.63 \%, \mathrm{n}=10)$, pancolonic (L2+L4) $(10.23 \%, n=9)$, and jejunoileal $(\mathrm{L} 1+\mathrm{L} 4)(2.33 \%, \mathrm{n}=2)$.

According to the phenotypic classification of $\mathrm{CD}$, the stenotic phenotype (B2) was the most prevalent $(35.23 \%$; $=31)$, followed by the nonstenotic and nonpenetrating/inflammatory (B1) $(25 \%$; $\mathrm{n}=22)$ and penetrating/fistulizing (B3) $(23.86 \% ; \mathrm{n}=21)$. However, $15.91 \%(n=14)$ of patients were lacking a classification (Table 1).

TABLE 1. Number and proportion of patients with Crohn's disease according to location and phenotype. May to July 2016, Rio de Janeiro, Brazil

\begin{tabular}{|c|c|c|c|}
\hline \multicolumn{2}{|c|}{ Variables } & \multirow{2}{*}{$\mathrm{n}$} & \multirow{2}{*}{$\%$} \\
\hline Localization & Intestinal phenotype & & \\
\hline \multirow{3}{*}{ Ileocolonic (L3) } & Stenotic (B2) & 19 & 21.59 \\
\hline & Inflammatory (B1) & 7 & 7.95 \\
\hline & Penetrating (B3) & 19 & 21.59 \\
\hline \multirow{3}{*}{ Colonic (L2) } & Stenotic (B2) & 5 & 5.68 \\
\hline & Inflammatory (B1) & 7 & 7.95 \\
\hline & Penetrating (B3) & 1 & 1.14 \\
\hline \multirow{3}{*}{ Ileal (L1) } & Stenotic (B2) & 5 & 5.68 \\
\hline & Inflammatory (B1) & 3 & 3.41 \\
\hline & Penetrating (B3) & 1 & 1.14 \\
\hline \multirow{2}{*}{ Pancolonic (L2+L4) } & Stenotic (B2) & 2 & 2.27 \\
\hline & Inflammatory (B1) & 3 & 3.41 \\
\hline \multirow{3}{*}{ Jejunoileal $(\mathrm{L} 1+\mathrm{L} 4)$} & Inflammatory (B1) & 1 & 1.14 \\
\hline & Penetrating (B3) & 1 & 1.14 \\
\hline & Not identified & 14 & 15.91 \\
\hline Total & & 88 & $100 \%$ \\
\hline
\end{tabular}

Of the 252 patients with $\mathrm{CD}, 17.46 \%(\mathrm{n}=44)$ had some type of perianal disease and $12.69 \%(n=32)$ had undergone a surgical procedure owing to disease complications (Figure 3).

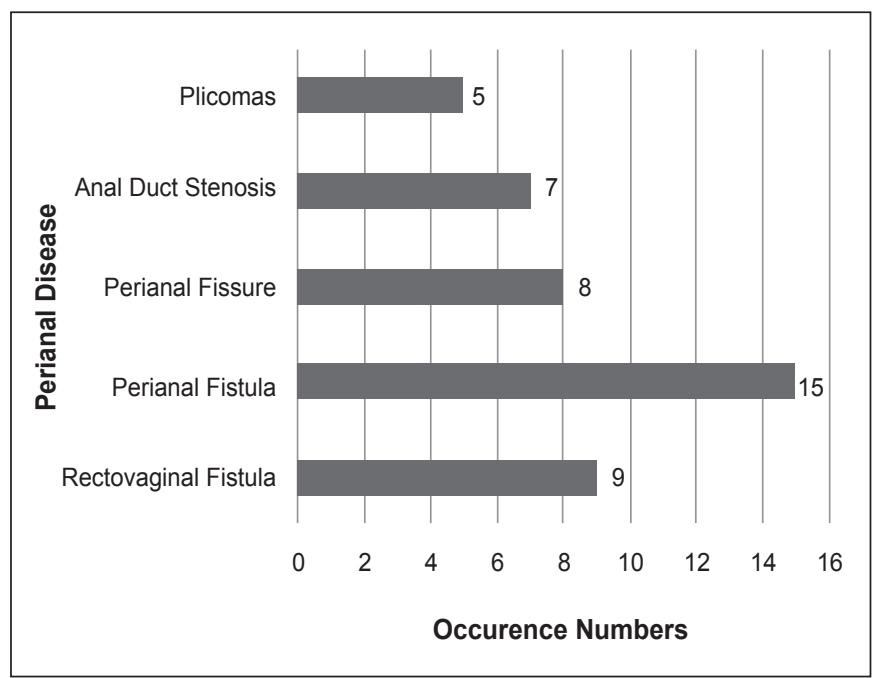

FIGURE 3. Distribution of occurrence numbers for perianal disease. Rio de Janeiro, Brazil, 2016.

\section{DISCUSSION}

The results of this study showed a predominance of female patients, thus corroborating other studies performed in Brazil. The data released in April 2016 by the department of pharmaceutical care and strategic inputs of the state of Rio de Janeiro are consistent with those obtained in the outpatient service. That publication indicated that $58.92 \%$ of patients with IBD were women and $41.08 \%$ were men $^{(3,4,8,14)}$. In contrast, most European studies showed a higher prevalence of IBD among men; in European countries, women primarily develop $\mathrm{CD}$ and men develop $\mathrm{UC}^{(2,12)}$.

Young adults are commonly diagnosed as having both $\mathrm{CD}$ and UC. Most new diagnoses were in the age group of between 15 and 40 years, whereas another peak of incidence was between 50 and 80 years ${ }^{(4,11,15)}$. Concerning the age group of the patients included in this study, most cases of IBD occurred at age between 30 and 45 years, whereas another peak of incidence occurred around age 60 years. The results found in this study contradict those found in the international literature. Most studies indicated a higher prevalence of IBD in white patients, followed by dark-skinned, black, and yellow patients, which was confirmed in this study population with a higher prevalence of IBD in white women ${ }^{(2,3,14,15)}$.

The demographic profile of patients showed a similarity to other Brazilian reference centers that offer health care to patients living in neighboring regions. It is noteworthy that patients usually travel great distances to seek specialized medical services. This indicates the need for expanding the coverage of more complex services to ensure access and proper use for all patients who need such services. Although telehealth defined as health-care services provided to people separated by distance and time is available by using technologies such as telephones, computers, or interactive video streaming, these resources are underutilized in South America for improving patient assistance programs despite the widespread use of both landlines and cell phones by these populations ${ }^{(13)}$. 
Similar to the epidemiological studies on the profile of patients with IBD conducted by Kleinubing-Júnior et al. and Barros et al., the extent of involvement of UC in this study showed a prevalence of extensive colitis (E3) and rectitis/proctitis $(\mathrm{E} 1)^{(3,8)}$.

The Montreal classification, owing to its diagnostic and therapeutic implications, has been increasingly used in patients with CD. In most studies related to classification according to location, the ileocolonic type was the most frequent, followed by the ileal and colonic types $^{(2-6,8-10,12,14)}$. In this study, patients with CD showed a higher prevalence of the ileocolonic type (L3), corroborating the results of recent multicenter studies that included countries in Europe, North America, and Oceania ${ }^{(2)}$.

However, the data found in this study showed a greater prevalence of patients with CD in the colonic region (L3) than in the ileal region (L1). Multicenter and review studies have pointed out that the nonstenotic and nonpenetrating/inflammatory phenotype (B1) is the most frequent ${ }^{(2,5)}$. Considering the phenotypic classification of $\mathrm{CD}$, the patients evaluated in this study were not predominantly found as having an inflammatory phenotype, as described in the literature. Most patients showed a penetrating phenotype, followed by the stenotic and inflammatory phenotype, respectively, with a slightly different percentage, which may be because of the low number of participants assessed with this classification.

The natural history and clinical progression of IBD are rather heterogeneous: up to $20 \%$ of patients with ulcerative colitis need to undergo a colectomy owing to the complications of the disease, whereas $>50 \%$ of patients with CD require surgery within 10 years after the diagnosis. On the other hand, up to $50 \%$ of patients with ulcerative colitis and $30 \%$ with CD tend to show a relatively passive disease progression without the need for immunosuppression or surgery ${ }^{(13)}$.

Therefore, the findings in the literature are in contrast to the results of this study, which showed that patients with CD needed more surgical procedures than those with IURC. Surgical approaches were performed in $12.69 \%$, that is, $<20 \%$ of patients with $\mathrm{CD}^{(5,13)}$. Perianal disease affects approximately $33 \%$ of patients with $C D$ after 10 years of disease progression and presents a high morbidity, mainly due to pain and drainage in the area, which may lead to complications such as dermatitis and pruritus.
The most frequent types of injury are perianal fistula, abscess, fissure, plicoma, and stenosis, as confirmed by a Brazilian metaanalysis of 67 articles in 2012. Some studies found perianal involvement in approximately $26 \%$ of patients with $\mathrm{CD}^{(4,7,13)}$.

This study found a lower prevalence of perianal disease than did other available studies. The most frequent type of injury was perianal fistula, followed by abscess, fissure, plicoma, and stenosis. In this manner, the occurrence of perianal disease and the percentage of surgical approaches described in this study did not exceed those described in domestic and international studies ${ }^{(4,5)}$.

\section{CONCLUSION}

The data from the analysis of the epidemiologic profiles of patients with IBD in this reference center in Rio de Janeiro showed great similarity with the profiles found in national studies; however, in general, nationwide studies to verify possible regional variations in the epidemiologic profile have not been performed throughout the country.

The demographic data of patients demonstrated the need for expanding specialized medical services and the use of strategies supporting distance interventions that provide comprehensive health care for patients.

The phenotypic classification of patients with CD did not show a prevalence of the inflammatory phenotype, as described in the literature. The observed high prevalence of the stenotic phenotype indicates the need for further investigations in this field of study in Brazil.

In conclusion, the other results of this study agree with those in the international literature. This study is expected to be useful for other researchers and may serve as a basis for welfare policies for patients with $\mathrm{CD}$ and $\mathrm{UC}$ in Brazil, leading to a more effective and safe therapy for these patients.

\section{Authors' contributions}

Santos RM, Carvalho ATP, Silva KS, Sá SPC, Santos AH, Sandinha MR participated in the planning, investigation, preparation of the manuscript, approval, and final submission to Arquivos de Gastroenterologia.

Santos RM, Carvalho ATP, Silva KS, Sá SPC, Santos AH, Sandinha MR. Doença inflamatória intestinal: perfil do paciente em tratamento ambulatorial. Arq Gastroenterol. 2017;54(2):96-100.

RESUMO - Contexto - A Doença de Crohn e a retocolite ulcerativa idiopática são as duas principais formas de doença inflamatória intestinal e possuem crescente incidência e prevalência, tendem a ser progressivas, cursam com recidivas frequentes e assumem formas clínicas de alta gravidade. No Brasil a escassez de dados epidemiológicos relacionados a tais agravos deixa essas pessoas em estado de vulnerabilidade e contribui para o aumento da morbidade. Objetivo - Descrever o perfil dos pacientes portadores de doença inflamatória intestinal atendidos em um ambulatório de doenças inflamatórias intestinais do estado do Rio de Janeiro. Métodos - Trata-se de uma pesquisa documental retrospectiva, exploratória, descritiva em abordagem quantitativa, realizada de maio a julho de 2016, em uma policlínica universitária, localizada no Rio de Janeiro, em ambulatório de tratamento de doenças inflamatórias intestinais. O estudo foi aprovado pelo Comitê de Ética em Pesquisa da instituição CAAE: 55179316.6.0000.5259/2016, e contou com 556 participantes. Resultados - Os dados revelam um predomínio das doenças inflamatórias intestinais, nos pacientes do sexo feminino, de cor branca. A doença de Crohn foi diagnosticada em um maior número de indivíduos em relação a retocolite ulcerativa idiopática. Os dados do perfil de localização intestinal mostram a região ileocolônica como mais afetada na doença de Crohn. Foi evidenciado predomínio do fenótipo estenosante na doença de Crohn. Conclusão - O predomínio do fenótipo estenosante na doença de Crohn, evidencia a necessidade de estudos aprofundados sobre a temática no Brasil. No mais, os dados obtidos demonstram um perfil epidemiológico da população semelhante ao divulgado em estudos nacionais e internacionais. DESCRITORES - Doenças inflamatórias intestinais. Doença de Crohn. Colite Ulcerativa. Epidemiologia. 


\section{REFERENCES}

1. Amo L, Gonzalez-Lama Y, Suarez C, Blazquez I, Matallana V, Calvo M, et al Impact of the incorporation of a nurse in an inflammatory bowel disease unit. Gastroenterol Hepatol. 2016;39:318-23.

2. Bardhan KD, Simmonds N, Royston C, Dhar A, Edwards CM; on behalf of the Rotherham IBD Database Users Group. J Crohns Colitis. 2010;4:405-12.

3. Barros PAC, Silva AMR, Neto MAFL. The epidemiological profile of inflammatory bowel disease patients on biologic therapy at a public hospital in Alagoas. J Coloproctol (Rio J). 2014;34:131-5.

4. Bechara CDS, Lacerda Filho A, Ferrari MDLA, Andrade DAR, Luz MMPD, Silva RGd. Montreal classification of patient operated for Crohn's disease and identification of surgical recurrence predictors. Rev Col Bras Cirurg. 2015;42:97-104

5. Cleynen I, Boucher G, Jostins L, Schumm LP, Zeissig S, Ahmad T, et al. Inherited determinants of Crohn's disease and ulcerative colitis phenotypes: a genetic association study. Lancet. 2016;387:156-67.

6. da Rosa JR, da Silva Júnior JF, da Rosa MI. Perfil epidemiológico de portadores de doença inflamatória intestinal Arq Catarin Med. 2014;43:53-8.

7. Eglinton TW, Barclay ML, Gearry RB, Frizelle FA. The spectrum of perianal Crohn's disease in a population-based cohort. Dis Colon Rectum. 2012;55:773-7.

8. Kleinubing-Júnior H, Pinho MSL, Ferreira LC, Bachtold GA, Merki A. Perfil dos pacientes ambulatoriais com doenças inflamatórias intestinais. ABCD, Arq Bras Cir Dig. 2011;24:200-3.
9. Oliveira FM, Emerick APC, Soares EG. Aspectos epidemiológicos das doenças intestinais inflamatórias na macrorregião de saúde leste do Estado de Minas Gerais. Ciênc Saúde Coletiva. 2010;15(Suppl 1).

10. Rebelo A, Rosa B, Moreira MJ, Cotter J. Da Classificação de Viena para a Nova Classificação de Montreal: Caracterização Fenotípica e Evolução Clínica da Doença de Crohn. J Portug Gastrenterol. 2011;18:99-100.

11. Ricci Jr JER. Segurança e riscos do tratamento da doença inflamatória intestinal durante gravidez e aleitamento. HU rev.2011;37(3),set.

12. Shirazi KM, Somi MH, Bafandeh Y, Saremi F, Mylanchy N, Rezaeifar P, et al Epidemiological and clinical characteristics of inflammatory bowel disease in patients from northwestern Iran. Middle East J Dig Dis. 2013;5:86-92.

13. Solberg IC, Lygren I, Jahnsen J, Aadland E, Høie O, Cvancarova M, et al. Clinical course during the first 10 years of ulcerative colitis: results from a population-based inception cohort (IBSEN Study). Scand J Gastroenterol. 2009;44:431-40.

14. Souza MM, Belasco AGS, Aguilar-Nascimento JE. Perfil Epidemiológico dos Pacientes Portadores de Doença Inflamatória Intestinal do Estado de Mato Grosso. Rev Bras Coloproct. 2008;28:324-8.

15. Squires SI, Boal AJ, Naismith GD. The financial impact of a nurse-led telemedicine service for inflammatory bowel disease in a large district general hospital. Frontline Gastroenterol. 2016;7:216-21. 